MOLESTO: Edebiyat Araştırmaları Dergisi

\title{
THE INTERCULTURAL CHALLENGE - ROMANIAN CULTURAL REPRESENTATIONS OF TURKISH IDENTITY
}

\begin{tabular}{|l||} 
\\
Gänderildiği tarih: \\
17.03.2019 \\
Kabul edildiği tarib: \\
02.07.2019 \\
Yaynlanma taribi: \\
30.07.2019 \\
\hline \hline Article Info \\
Date submitted: \\
17.03.2019 \\
Date accepted: \\
02.07.2019 \\
Date published: \\
30.07.2019 \\
\hline Balgisi \\
\hline
\end{tabular}

emotions.

\section{Marina Cap-Bun ${ }^{1}$}

\begin{abstract}
Romanian culture developed a special interest for Oriental themes, embodied in various forms of artistic manifestations, so that, in time, a number of writers (Dimitrie Cantemir, Cilibi Moise, Anton Pann, Dimitrie Bolinineanu, Mihail Sadoveanu, Ion Barbu, Mateiu Caragiale, Eugen Barbu, Silviu Angelescu among them), dramatists (Ion Luca Caragiale, Victor Ion Popa), painters (Theodor Aman, Nicolae Tonitza), musicians (Dimitrie Cantemir, Anton Pann) have become well-known for being perceptibly attached to the Turkish world, and for the developing a specific lexis in order to praise the magnificence and wisdom of the Orient.

Keywords: Culture, Romania, Turkey, Dimitrie Cantemir
\end{abstract}

Romanian culture developed a special interest for Oriental themes, embodied in various forms of artistic manifestations, so that, in time, a number of writers (Dimitrie Cantemir, Cilibi Moise, Anton Pann, Dimitrie Bolinineanu, Mihail Sadoveanu, Ion Barbu, Mateiu Caragiale, Eugen Barbu, Silviu Angelescu among them), dramatists (Ion Luca Caragiale, Victor Ion Popa), painters (Theodor Aman, Nicolae Tonitza), musicians (Dimitrie Cantemir, Anton Pann) have become wellknown for being perceptibly attached to the Turkish world, and for the developing a specific lexis in order to praise the magnificence and wisdom of the Orient.

At the beginning of the nineteenth century, the influence of the European Romanticism enhanced this appeal of the exotic Oriental world, but, at the same time, brought about a strong emphasis on national identities, mainly manifested as glorification of the past, revival of the local myths and folk arts, portraying of the natural splendors of "the book of nature", and intense, sometimes conflicting,

But the historic intercultural relation between the two cultural spaces had been controversial, even before Romanticism with its taste for antinomy and ambiguity. "The Turk" has not been constantly seen as the charismatic citizen of a glorious empire, but sometimes was represented as "the other" (mainly in terms of religion and ethnicity), or even "the enemy". While Romanian intellectuals were traveling to Constantinople they were always admirers of the grandeur of the Ottoman Empire, of Oriental architecture and civilization, and the same appreciation was extended to literature, music, visual arts, habits and ways. But whenever this sympathetic cultural awareness was confronted with the Romanian ethnic sensibility, molded by the long history of military conflicts, in other words, when a historic subject was involved, a total change in attitude has occurred.

What I intend to discuss here is not a comprehensive history of the Romanian-Turkish intercultural relations (which would certainly involve a long term research project), but this obvious gap between the cultural sensibility and the ethnic one, illustrated by a limited number of case studies.

The first Romanian intellectual exemplifying this kind of problematic relationship is the Moldavian Prince Dimitrie Cantemir (1673-1723), a famous writer, historian, musician, ethnographer of his times, who has spent almost half of his life in Constantinople (1687-1710), in forced exile, where he had become fluent in Turkish, so that he was able to document for his famous History of the Growth and Decay of the Ottoman Empire (Incrementorum atque decrementorum Aulae Otbmannicae libri tres), and for a history and notation of Ottoman court music. Recognized as a famous Orientalist, Cantemir fully enjoyed the luxury of Turkish

${ }^{1}$ marina capbun@yahoo.com Prof. Dr. Universitatea Ovidius Constanta

Temmuz 2019 
life, together with the confidence and favors of Sultan Ahmed III, during his residence in the heart of the Ottoman Empire, living in his beautiful palace with a garden and a lake.

His relation with the cultural space of his long exile is best described by the Vita et Elogium Principis Demetrii Cantemyrii justifying his nomination as a full member of the Academy of Sciences in Berlin (founded by Leibnitz), in 1714:

Throughout his 22-year stay in Constantinople he practiced Oriental languages, cultivated poetry and music, which he composed after the Turks' liking, with scores, and was much loved by the Sultan, the Vizier, and other dignitaries. (Pop, 841-42.)

Professor Virgil Cândea, who discovered the definitive original Latin manuscript of the History, in 1984, at Houghton Library, University of Cambridge, Massachusetts, fully understood Cantemir's mixed feelings:

But even beyond the Prince's hostile attitude towards the state that subjugated his country at the time, one must acknowledge his objective, even sympathetic approach to the values of Islam. Not only in the annotations of his History but also, and mainly, in his System of the Mahometan Religion (written in Latin in 1719, Russian version published in 1722), Cantemir offered a fascinating picture of the faiths, culture, education and mores of Islamic peoples. That was the first extensive work introducing the history of the Moslem civilization to the European scholarly circles; naturally, it was written from the vantage point of a faithful guardian of the European tradition of thinking, but it also evinced a sympathetic understanding of the intellectual, moral and artistic values of the Islamic world. Cantemir did not hesitate to praise the specific approaches and attitudes, literary and musical works, educational system and moral standards of the Arab, Turkish and Persian peoples, and he often openly stated his empathy with such realities, displaying the assurance of one who knew them from first-hand experience. (Cândea, LXXVI)

Florentina Nicolae, another Cantemir scholar, confirms that Cantemir's attitude was that of "a scientist, aware that he was able to offer both the Orient and the Occident a pertinent analysis of an insider". She also insists that "he has remained Romanian and Orthodox Christian" in everything he has wrote (Nicolae, 331). And we have to agree with that, as in spite of his cultural and civilizational admiration to the Ottoman Empire, when he was in the position to take a historic decision as a Prince of Moldova he joined Peter the Great in the Russo-Turkish War (1710-1711) and placed the country under Russian suzerainty.

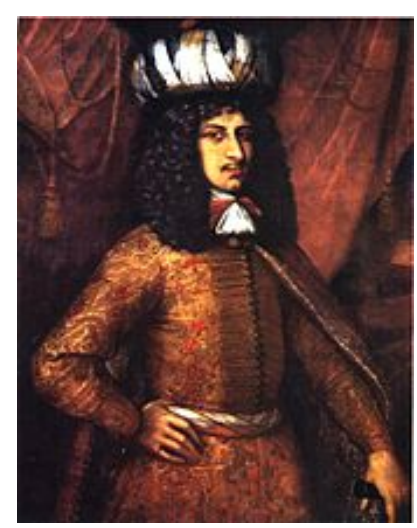

Dimitrie Cantemir in Ottoman dress, unknow artist

Also charmed by the Turkish world, and also an exile finding hospitality in the empire was the poet Dimitrie Bolintineanu (1819-1872), who wrote a cycle of poems of Oriental inspiration, called The Flowers of the Bosphorus (Florile Bosforului), first published in 1855. Later on, he translated some of these poems into French and incorporated them in the anthology Brises d'Orient, published in Paris, in 1866, as the Romanian Cilt 2 / Say 2 
romantic poet, like his French contemporaries (Volney, Hugo, and Lamartine included), was truly fascinated with Oriental opulence.

Like many (monogamous) European travelers, Romanians are somehow envious and secretly longing for a personal harem. Maria Todorova noticed that the Orient is sometimes a "metaphor for the forbidden", due to "the explicit relationship between the Orient and the feminine". She has also argued that "oriental discourses involve a theory of sexuality and sensuality in the disguise of a theory of asceticism". (Todorova, 13). I doubt that Todorova had known The Flowers of the Bosphorus (even those available in French), but this poetic cycle exemplifies her theory.

Convinced that poetry's beauty is eternal, unlike that of women, which is ephemeral, Bolintineanu immortalized some charming female portraits, in verses which are imbued with love, lust, and sensuality. The girl from Candili (Fata de la Candili) is only one example of heavenly beauty for which the nightingales (Biulbiuli) are singing and "the stars remain silenced” („Stelele se amuțesc”). In Guffar, the splendor of the Oriental dance of "the sweet slaves" is evoked, being compared with the rays of sunshine glittering on the sea. Dilrubam is bathing like a nymph, while the limpid waters are mirroring her entire brilliance, and so is Almelaiur, dancing with the dolphins in complicated and sensual playoffs. And so on, and so forth.

The Paradise like images of a glorious nature, usually depicted in springtime (Ilbahar), are balanced by the tragic stories of the flower-girls (a habitual metaphor in Romanian folklore) of the Bosphorus, almost organically growing in this heavenly gardens, most of them slaves in the harems, who are experiencing real misfortunes, being always ready to sacrifice themselves for their love, or for the sake of their children. The typically romantic contrasts are constantly present on their beautiful looks, revealing "a happy smile on a suffering face” („un surâs ferice p-un chip suferind”).

The Turkish Sarai, with its endless conspiracies, becomes the perfect exemplification of the consubstantiality of love (with its blind lust) and death (always threatening to punish inappropriate desires). Love also combines with the harshest jalousie and with an endless craving for power and influence, so the life of a rival who charms the Sultan is always in danger. Consequently, a poem like Rabié becomes a veritable carpe diem:

Hurry to taste, as long as your life still sparkles, / This beauty which sweetly captures us / This eternal magic, these gleams / That sweetly caress your blazing senses / And fuddle your soul and make it flinch / Under the hand of providence, of love and delight! / Oh! Tomorrow your dust will fly to the winds! / As death lays veiled in the short-lived flower (Grăbeşte-te de gustă, cât viaţa ta lucește, / Această frumusețe ce dulce ne răpeşte, / Ăst farmec fără moarte, aceste străluciri / Ce răsfăţându-ți dulce arzândele simțiri, / Îmbată al tău suflet şi-l face de tresare / Sub mâna providenței, d-amor şi desfătare!/ Oh! Mâne-a ta țărână de vânt se va răpi! / Căci moartea stă ascunsă sub floarea de o zi...)

Validé, the Sultan's mother, carefully keeps the fragile balance of this troubled world, strictly applying the traditional rules of the harem, to maintain the order and discipline, and to ensure descendants for the dynasty.

Women's condition is accurately contemplated by Bolintineanu, who observes that the noble ladies belonging to the dynasty are punished with the same brutality like the slaves. Both the slave Leili, who had fallen in love with Ali, and the Sultan's daughter Suadé, who had disobeyed her father's choice, are cruelly thrown into the sea. In the homonymous poem, Fatmé, the beautiful sister of Sultan Abdul Medjid, finds her newborn baby strangled, a crime allowed by the Muslim law of succession, and she dies in distress, a fact which persuades the Sultan to change the cruel law. The poem apparently versified a true story, as the editor of the 1865 edition specifies that "this history is very well-known in Constantinople". Dramatic accents are also to be found in The Curse of the Dervish (Blestemul dervisului) a poem building on the belief that a dervish's curse, which is to be feared by the Sultans themselves, always comes true.

When the beautiful slave Mehrubé, coming from the poet's native land, affronts Sultan Selim by confessing her love for a handsome son of the Carpathians, and for her "sweet and lovely" native language, and she is consequently drowned into the sea, Bolintineanu becomes even more distressed with regard to 
the condition of woman slaves. His ethnic sensitivity becomes stronger than his cultural admiration of the Ottoman world.

The same mechanism is recognizable when the Romanian poet, author of numerous historic legends, versifies various battles between his country's army and the Ottoman one. Even if he always courteously describes the military force "the enemy", he also celebrates the Romanian victories on the battlefields. Another typical conflicting situation is to be found in the poems describing the visits of the Turkish envoys in Walachia. While Mircea the Eldest, although he is ready to go to war to defend the independence of his country, asks his captains to "respect" the envoys (in Mircea the Great and the Envoys; Mircea cel Mare sii solii), Vlad the Impeller defies the empire by afflicting its emissaries. The Impeller and the Envoys (Țepess si solii) versifies a well-known historic episode, which tells the story of the messengers of Mahomet II, who came to dethrone Vlad, also sustained by the local treacherous boyars. But Vlad invokes his repeated fights for maintaining the suzerainty of Walachia and he is consequently acclaimed by the people. In a very cruel response to the request of the Ottoman Empire to abdicate, he drives nails into the heads of the envoys, as they had refused to take off their turbans, thus disobeying the local stately protocol.

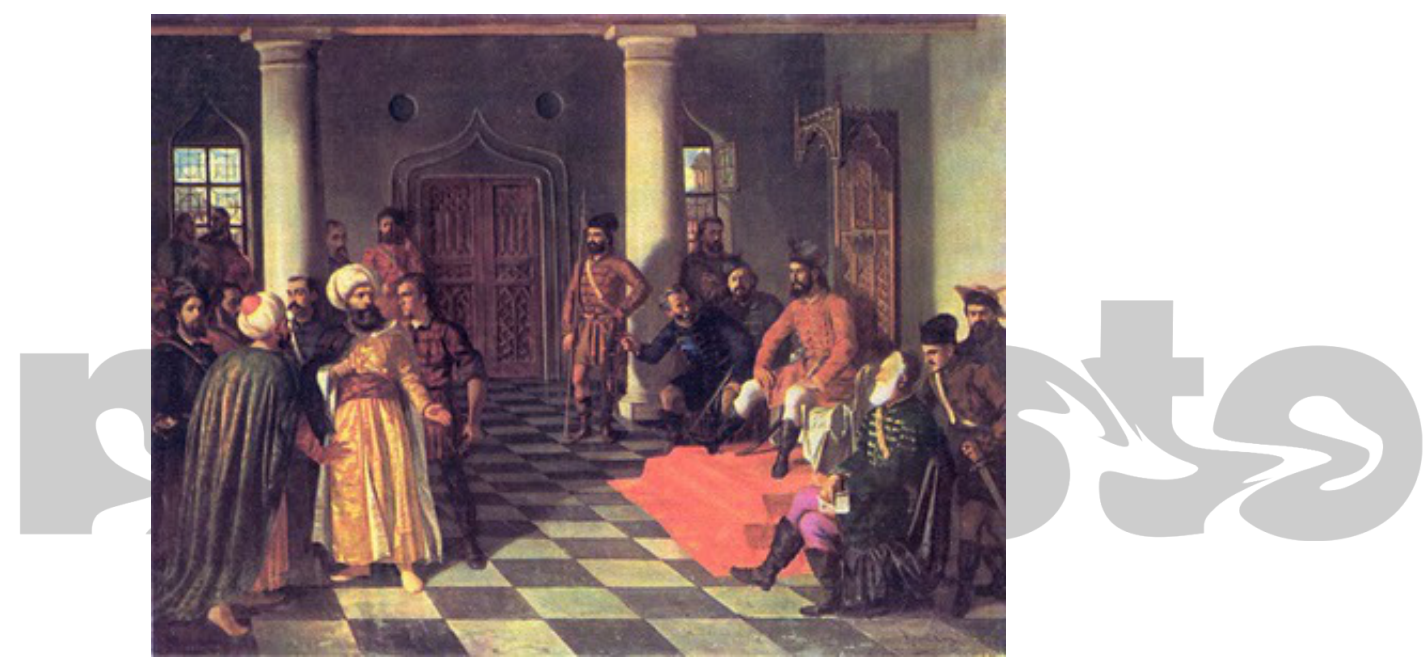

Teodor Aman, Vlad the Impeller and the Turkish Envoys

The same historic episode is also the subject of a famous painting by Teodor Aman (1831-1891), Vlad the Impeller and the Turkish Envoys. The painter accurately reproduces the psychology of his characters, the bold majesty of Vlad, chromatically enhanced by the dominance of red, which also recalls his legendary thirst for blood, being contrasted by the uneasy reverence of the emissaries, who had certainly heard rumors of his cruelty. The only warm color on the left side of the painting is the yellowish, gold like dress of one of the Turks, which symbolizes both the magnificence of the victorious warrior, and the justified anxiety in his looks. The contrastive spatial relations are also extended to the secondary characters: while Vlad's loyal companions proudly revere him, the boyars who had accompanied the envoys, hoping to witness the dethronement, do not dare to look towards him and cowardly hide in the dark corners of the room or behind the pillars. The distribution of the characters is also evocative of the Romanian mythology, which has consecrated an ethical allotment of the spatial vectors: the right is always reserved for the good things, while the left brings about evil effects. Hence, the "positive" characters (judging from the point of view of Aman's ethnic and patriotic sensibility) are on the right side, while the "negative" ones are on the left. The checkerboard like floor, suggesting the games of power, always won by the keen and daring players, creates the dynamic black and white background, which allows a better scrutiny of the contrasts, not only in terms of colors and spatiality, but also the ingenious game of lights and shadows, of center and back stage.

Aman also painted various scenes of battle: The Battle of Alma (Bătălia de la Alma), which was exposed in Paris in 1855, The driving out of the Turks at Călugăreni (Izgonirea turcilor la Călugăreni), The Battle of 
MOLESTO: Edebiyat Araştırmaları Dergisi

Romanians with the Turks in the island Saint George (Bătălia românilor cu turcii in insula Sf. Gheorghe). He has presented his painting The Battle from Olteniţa (Bătălia de la Olteniţa,) to the Sultan, trying to impress him.

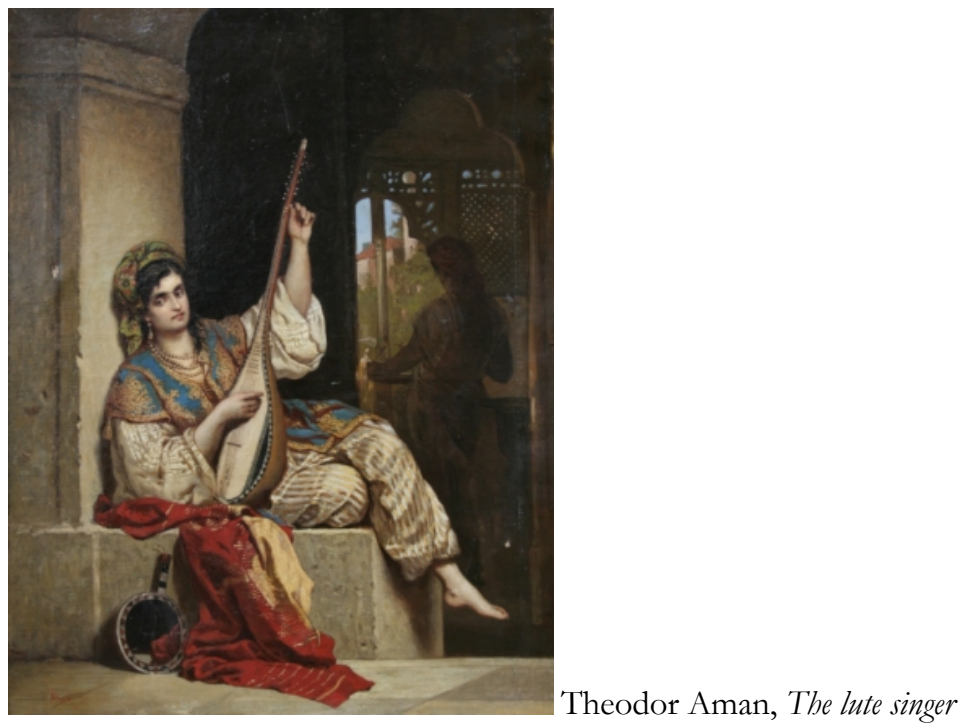

But beyond the historic themes that awakened his ethnic and patriotic sensibility, Aman was also fascinated by the Turkish subjects. He painted numerous odalisques, in various postures, Sarai interiors, and scenes of the harems. Many of them visualize the same atmosphere as Bolintineanu's Flowers, implying motives like gorgeousness, youthfulness, music, dance, vibrant colors, lechery and luxurious garments and jewels. In his Oriental paintings, Aman proves the same artistic craftsmanship in illuminating the young and beautiful faces of the odalisques with either love and contentment or jealousy and frustration.

It thus becomes easy to conclude that Aman's paintings express the same complex mixture of admiration for the Turkish way of life, and Romantic impulse to glorify the Romanian past, as the verses of his contemporary poet Dimitrie Bolintineanu, a fact that clearly speaks of the esthetic cohesion of the 1848 generation.

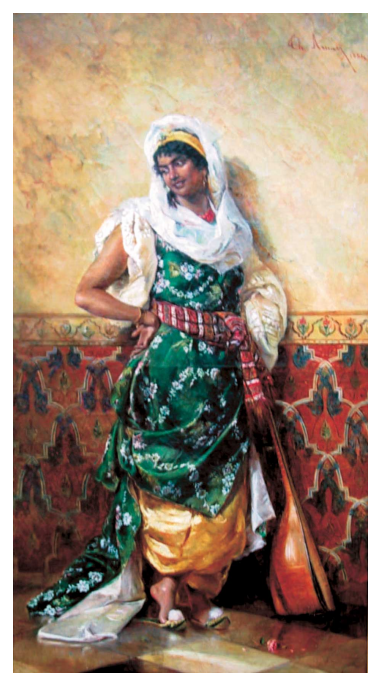

Theodor Aman, Odalisque

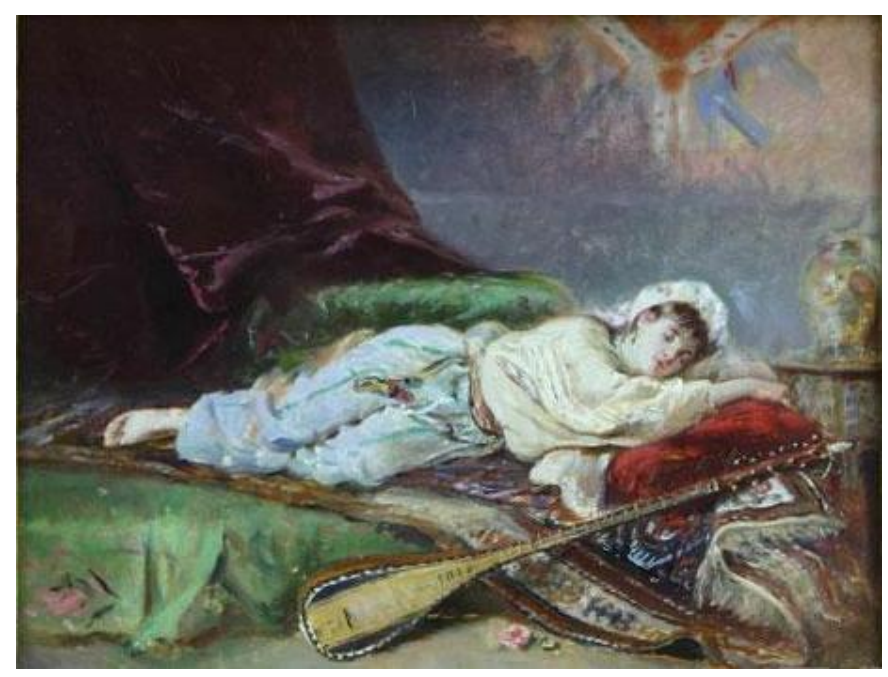

Theodor Aman, Odalisque sitting

The next cultural generation reveals different visions and attitudes, but conserves the mixed feelings towards the Oriental world. Mihai Eminescu, the most important Romanian poet of all times, has magnificently illustrated the gap between the sympathetic cultural awareness and the patriotic romantic perception, in his Third Letter (Scrisoarea III), a very well-known poem studied in high school textbooks. He 
imagined a mythological story of the Ottoman Empire, born from the symbolic wedding of a Sultan with the mighty moon:

Once upon a time a Sultan, ruler over nomad bands, / Roaming with their herds and seeking pastures new in many lands, / On the earth lay sleeping, pillowed was his head upon his arm, / But his eyes, beneath closed lashes, now awoke in dream's sweet charm. / From the sky down gliding gently, all in silver dress arrayed, / Came the moon towards him descending as a pure and lovely maid, / On her pathway, all around her, as on mild spring's step did bloom, / Yet her eyes were full of shadows born of secret sorrow's gloom, / All the woods with so much beauty charmed were thrilling with delight. / All the brooks and rivers quivered with their limpid faces bright, / Diamond dust was lightly falling from above like finest rain, / Glitt'ring in the air, on flowers, over all in nature's reign, / In the night resplendent rainbows arching on the sky were seen, / And bewitching, softly whispered, sounded music sweet, serene.../ Lovely arms she stretched towards him as he lay, her raven hair / Fell like silken waves down streaming on her snowy shoulders bare: / - "Let our lives be bound together, come beloved, to my breast, / Soothing balm to my sweet sorrow be thy sorrow, near me rest.../ This is Life's book for all ages on the stars did Fate record: / I must be thy sovereign lady, thou must be my life's dear lord"' (Eminescu, 201)

Soon, the Sultan's dream of love changes into one of glory, symbolically figured by the organic growth of a huge tree: "From his heart sprang up a tree that towards the sky its branches reared, / And it grew, it grew in moments as in ages long, this tree / Shot its boughs with massy foliage over all, on land and sea" (Eminescu, 202) The shadows of this gigantic tree soon embrace "all the boundless universe", a metaphor of the magnificent growth of the Ottoman Empire. Awaken from the prophetic dream, the Sultan recognizes "That in dream he had ascended in Mohammed's paradise, / And that from his love an empire would be born and wide would grow" (Eminescu, 203)

The prophetic dream comes true, generating an ever growing empire, as his descendants conquer "nation after nation" and "country after country", until "the stormy Bajazet" comes "full of glory" to the Danube, which proves to be an unshakable limit, due to the strong, organic roots of the Romanian people, "a wall / That by fear is never shaken, nothing ever makes it fall!". The battle between Bajazet's great army and that of Mircea the Eldest, the ruler of Walachia, is labeled like a cosmic confrontation of elements.

Bajazet invokes the glorious victories of his army, compared with the extreme frenzies of nature: "the crescent's furious storm", "the thunder that most direful earth and sea with rage had rent", "my hurricane, that's sweeping all away like dust and chaff” (Eminescu, 205).

On the other hand, Romanian army is described in similar terms, "this fierce storm so widely rushing", "victoriously advancing":

Like a dust cloud, storm foretelling, lightly, swiftly on they sped, / Shield on shield gave back the sunlight, spear points glittered over head, / As from copper clouds in autumn hail storms driven by the blast, / Hide in darkness the horizon, so sharp arrows flashing passed, / Whizzing, singing, hurtling, ringing, filled the air with dread alarms, / And to thundering horsehoofs echoed cries of battle, clash of arms. (Eminescu, 207)

Eminescu is obviously impressed by the Turkish army, and by the magnificent history of the empire, but his ethnic sensibility dictates him to equally glorify the medieval history of his native land, and to celebrate the particular victory of the Romanian army in the battle of Rovine.

An interesting case study is Ion Luca Caragiale (1852-1912), the greatest Romanian dramatist of all times and an equally interesting prose writer, has often reflected on the literary perfume of the multicultural identities. His own complex Balkan origins might have been cause for this attitude, as he came from a multicultural and multiethnic family. His father's ancestors left their native island (Hydra, a Greek island inhabited by an Albanian minority) and went to live in the famous Greek neighborhood of Phanar in Istanbul. Caragiale's grandfather Ştefan worked as a chef for Caragea, who became the ruler of Walachia in 1812, and brought his entire household to Bucharest. Ştefan had three sons: Luca, Caragiale's father, who was born in 1812 in Istanbul and came to Bucharest as a newborn baby, Iorgu and Costache. They contributed to the development of Romanian theater in its early days, being actors, stage directors, dramatic 
authors and translators, as well as founders and managers of one of the first theatrical schools in Romania. The young I.L. Caragiale was one of the first students of this school, and he later on worked for the National Theatre of Bucharest himself, first as a prompter, then as a translator and author of original plays, and finally, he became the director of the theater.

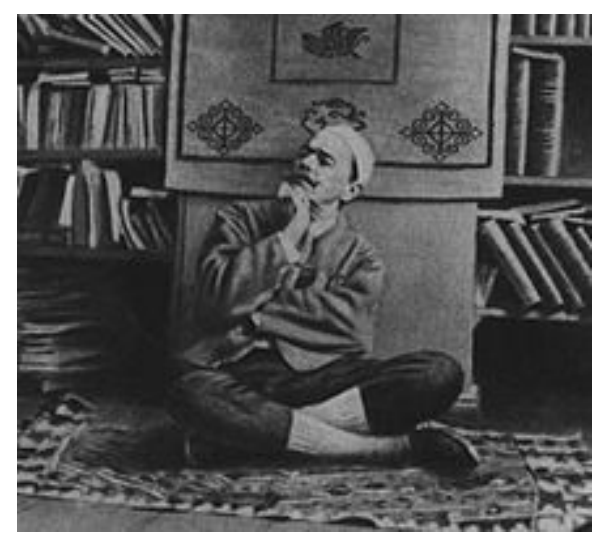

I.L. Caragiale in Oriental costume

All of these personal experiences created a complex cross-cultural identity, which is interestingly reflected in Caragiale's literary works, in which the Oriental themes and identities are explored.

An exquisite illustration of Caragiale's employment of the Oriental style is the sketch Fresh Prime Pastrami (Pastramă trufanda) first published in 1909, and then included in the volume New Sketches (Schițe noua) in 1910. In a note, the author explains that he heard the story in childhood, at Ploieşti, from an old Bulgarian barber, Kir Ştefan, and later found a variant of it in a French version of the Turkish anecdotes of Nasr-ed-Din Khodja. The main characters are two merchants: a Turk and a Jew, and eager to create a specific ethnic color, Caragiale presents Yussuf squatting and smoking in Turkish style, while traveling to Jerusalem for business. His Jewish neighbor Aaron asks him to deliver a "sack of cloths" to his brother who is living in the Holy City. During the trip, the Turk opens the bag, which "was crammed full with prime pastrami" and emanated a tempting smell, and eats everything, together with other travelers, with the intention of paying honestly for the firstling delicatessen he consumed. Upon his return, he learns that what he had eaten was not "genuine pastrami of mutton, but pastrami of Jew." Since Aaron's father demanded to be buried in Jerusalem, his son — an ingenious, typically Jewish merchant — salted his meat and asked his friend to deliver it to his brother in order to be buried there:

When Father died, he made me swear to send him to be buried in holy ground at Jerusalem; that was where he wanted to moulder away. I thought to myself that bones don't moulder; I buried them here and made the flash into pastrami. (Caragiale, 113)

So what happens in this story is rather a case of group cannibalism, suggesting the primeval nature of the eccentric and weird Oriental world. The case is unique for the wise Turkish judge (Cadi): "Well, I've been judging here at Cavalla for thirty years... all sorts of people, all sorts of cases; but I never met such madmen or such a queer case before!" The moral dilemma experienced by the Cadi, who is supposed to serve justice for the two former friends, is a metaphor for the strangeness of the Oriental world and for its incompatibility with European moral standards. Who is to be blamed more for such an odd, unprecedented situation: the hungry Turk whose stomach was stronger than his promise or the avaricious Jew who lied to his friend to save the money for the transportation of the dead body? The Cadi, a clear insignia of Oriental wisdom, punishes both of them, as both proved to be reckless.

The story also challenges the theoretical boundaries of a literary text, raising questions like: is it a comic theme or a tragic one? Both the moral and the aesthetic ambiguity implied here certainly illustrate the exotic and strange otherness of the Oriental world. Caragiale expresses here rather a Western nostalgia for Oriental values. In fact, during this time he had become a resident of civilized Western Europe, as he was living in Berlin. 
Turkish cultural identity is also investigated in the Oriental story of $A b u$-Hasan, which illustrates the typically Oriental luxury and leisure, but also the lust and the tendency to excesses of any kind. Published posthumously, the text was inspired form the Arabian Nights, being a short version of the story called The Sleeper Awakened (Le dormeur éveille), which also inspired Calderón de la Barca for his famous play Life is a Dream (La Vida Es Sueño). Caragiale discovered the story in the French edition of A. Galland, but his version is very particular. Eric D. Tappe commented upon the changes:

His treatment of Galland's text throws a light on his own methods as a storyteller. In the first place, his version is about half the length of Galland's. The leisurely and repetitive story of the French version, very suitable in the context of the whole Arabian Nights' Entertainment, where Scheherazade's object is to spin out her tale, becomes in Caragiale's version much more incisive. Secondly, the rather formal literary language used by the speakers in the French version becomes in the Romanian far more racy. It has the flavor of the language spoken at a period when Romanian society was less westernized than at the beginning of the twentieth century, and thus the language fits the atmosphere of the tale. (Tappe, 83)

Abu Hasan is the son of a rich merchant in Baghdad, who divides his inherited capital into two equal parts; one of the halves is rapidly exhausted in luxurious parties with phony friends and the other half is safely kept to allow him a decent existence for his entire life. Thus Abu Hasan illustrates both the wise and the reckless versions of the Oriental identity. After abandoning his former friends he takes to inviting a total stranger for dinner every evening. But one evening his unknown guest is the mighty caliph of Baghdad, Harun-al-Rashid, who was traveling disguised as a merchant. Asked by his guest about his most secret wishes, he expresses his desire himself to be the caliph of Baghdad for one day, a wish easily made possible by Harun-al-Rashid. Invested with both wisdom and the supreme power, Abu Hasan proves to be a good caliph, but also gives Caragiale a pretext to describe the luxury and leisure of the Oriental court.
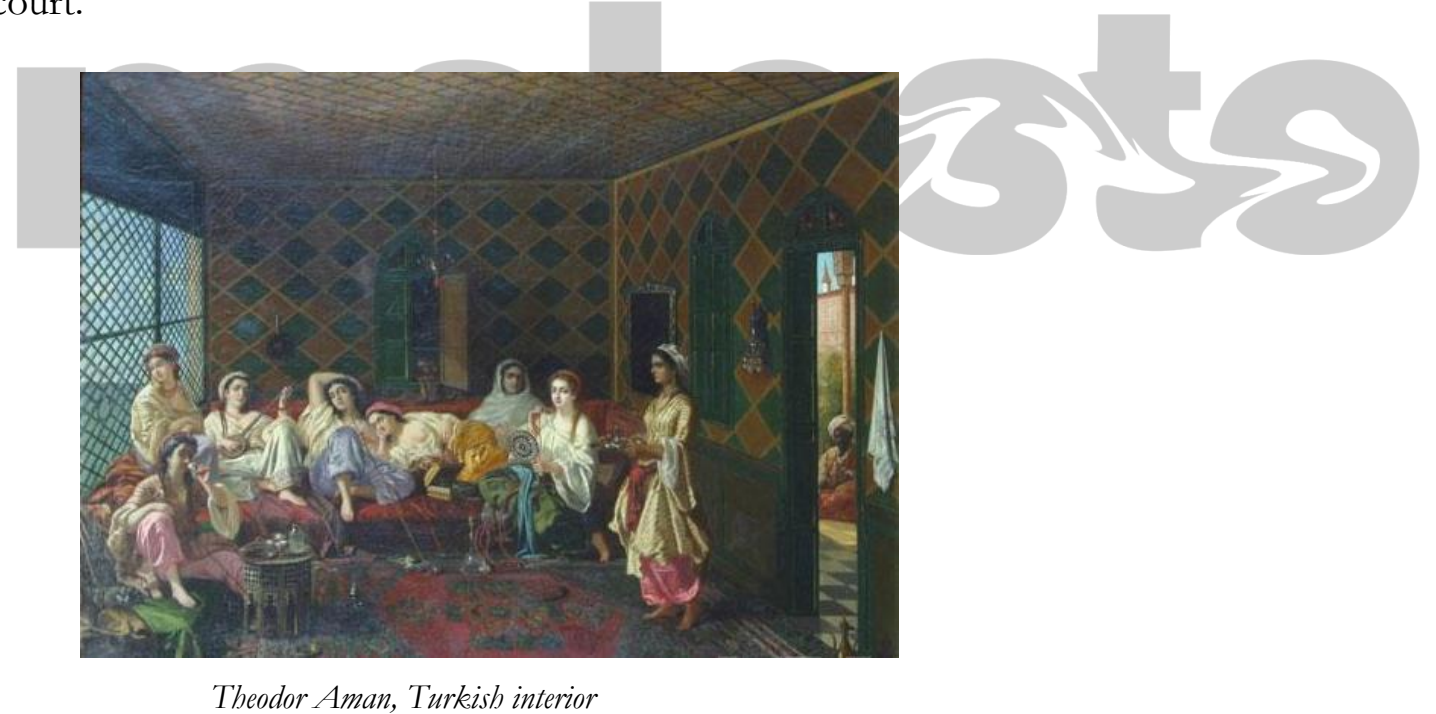

The next day Abu Hasan has serious problems in readjusting to his previous identity, so he grows mad and is imprisoned. This second charade played by his destiny makes him even wiser and happier, but only after a great deal of initiating anguish. The Oriental origin of the motif guarantees the author's search for exotic places, mentalities and a special type of adventure.

A few parodies in verses also invoke the exotic Orient. A poem called Oriental Noon (Amiază maură), published in 1893, in the journal Moftul român, realistically stages the conflict between two beautiful jealous wives who hate each other: the passionate brunette Fatmé and the blonde Biulbiul. They surround the Emir Ahmet with their competitive love, illustrating Oriental lust, and the odalisques' struggle for influence and power, almost recalling a scene of harsh confrontation between Mahidevran and Hurrem sultanas, from Suleyman the Magnificent, a television series which had a huge success in Romania. The erotic implications are only suggested by gestures, postures, and by the act of "secretly talking" fallowed by the fatigue and silence, but Caragiale succeeds in expressing the dramatic tensions inherent to this cultural model of marriage. 
Kir Ianulea. Oriental Anecdote (Kir Ianulea. Anecdotă orientală, 1909) also depicts a fascinating Oriental figure. A devil by origin, the main character becomes a married man in eighteenth century Bucharest, where his Black Emperor of Hell sent him to experience marriage and then report the wickedness of women. To clarify his presence and intention to settle down, he delivers a grotesque story of his life, pretending to be a Greek merchant "from the district of Mt. Athos". In spite of being a devil, Ianulea is a kind and loving husband in contrast to his inhumanly wicked wife Acrivița, "more perverse than a shedevil", who first ruins him and after that makes him run away from the creditors. But let us see what his being a Greek implies. At first he is rich, generous and loving, but he does not indulge his wife's passion for gossip. His wife's accusations of being an "Albanian infidel" and a "Turkish gypsy" (păgânul, arvanitul; cenghenè turcească) are only a way of hiding her own bad character. In fact, ethnic otherness is an ambiguous issue here, as being a Phanariot Greek in the eighteenth century Bucharest was hardly an unusual situation. The rulers of the country and their entire households were Greeks from Phanar and a great number of the merchants of that time were also Greeks, so the lifestyle, the manners, the fashion and the common vocabulary were all influenced by this situation. Cristina Valentina Dafinoiu made a thorough investigation of all the terms of Greek origin in this text, which build a linguistic atmosphere adequate to the time and place of the novella (Dafinoiu, 101-10).

It has been observed by literary critics that many of the scoundrels in Caragiale's works have Greek names. But the association of Balkan identity with bad temper does not express an individual prejudice of the author, a Greek himself. Rather it expresses a collective one, maybe a remote consequence of the cultural narcissism incriminated by Todorova.

What is really interesting here is the association of demonic nature with Ianulea's Greek origin. Even being a devil does not seem to impress the human characters such as the Romanian peasant Negoiță. When Ianulea reveals his real identity, Negoiță is far from stunned and placidly accepts the terms of the contract offered by the devil. The man is supposed to hide Ianulea and help him escape from creditors, and the devil pays him indirectly: he possesses some wealthy women of the time and he releases them only in the presence of Negoiță, who is well paid and soon becomes a famous exorcist. When the contract expires, Ianulea possesses the ruler's daughter to take his revenge on womankind. At the royal court in Bucharest, the devil finds a homely atmosphere, as "the Prince called to him in Greek, which in those days was the language of the nobility". Possessed by the devil, the girl asks to see her real father, Captain Manoli Ghaiduri, whom the author describes as being a remarkably beautiful man: "You don't often see such a fine figure of a soldier! Tall and broad with big moustaches - a splendid Albanian, and smothered in braid from head to foot - the pride of any court!" Negoiță is called again but the devil refuses to go, as he has already paid his debt to the man. Thus Negoiţă asks Ianuloaia (Ianulea's former wife) to come and relegate the devil. She takes over the exorcism business from Negoiţă with even greater success, as the devil prefers to flee back into Hell rather than see his wife again.

The issue of Phanariot Greek identity therefore is very complex in this historic novella - one-ofthe-kind in Caragiale's entire literary career. The idea of ethnic otherness is also projected into the theoretic dichotomy or the real and the fantastic as irreconcilable worlds. Here, the "bridge" between East and West becomes a crossroad of different levels of existence and their literary reflections. It is probably a way of justifying themes like the epistemic and moral mixture, the improvisation or the taste of conspiracy, which are indeed favorite topics in Caragiale's works. Once more, such thematic preferences lead us back to the generic Balkan features, as the epic atmosphere in Caragiale's Bucharest, is one of gratuitous and almost paranoid intrigue and conspiracy, always efficient in the process of escaping the banality of the real. But many features usually associated with Balkan identity are often attributed to Romanians as well. 


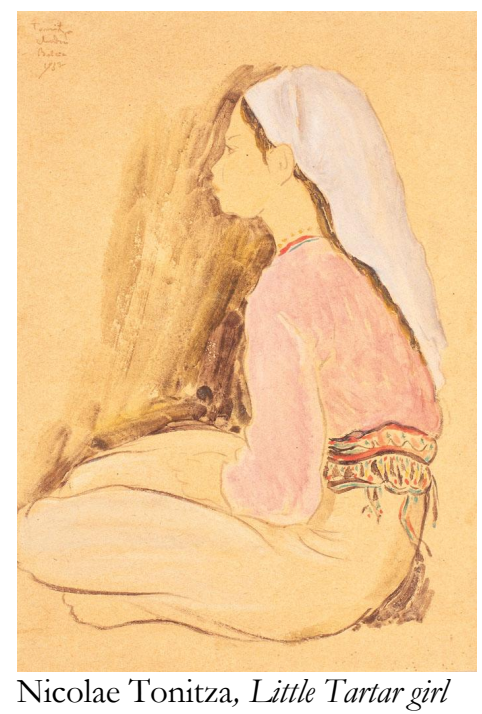

At the beginning of the twentieth century, and mainly in the interwar period, the fascination of the Turkish world is still active in Romanian culture. The best example to illustrate it is the poet Ion Barbu (1895-1961), Dan Barbilian by his real name, also a famous professor of mathematics at the University of Bucharest. His cycle Hissarlik is an exercise of pure admiration for the Turkish world, intended "for a fairer worship of Anton Pann's world", himself a well-established poet and musician of the nineteenth century (1796-1854), who mainly treasured the Balkan-Oriental values and folk traditions.

"Dear old Hissarlik", a hill near Troy, the Homeric Ilium, is the magic, ageless land of the mythical epos, in which the poet can project his reveries of Oriental perfection: "Turkey's pick and flower, / In a stagnant glory, power". This imaginary realm - "Torn from the rib of the sun!" - is located "On some Turkish Daube bank, / In some spent tobacco field, / In the midst of Good and Rank, / Breaking steps onto the skies / In full blossom it must rise: / What is white / What is right / Hissarlik!"

It is a kingdom where ethical and moral values are dissolved and the frenzy music and dance of the harem ravages the entire cosmos: "Out of cauldrons wrests a tune, / Odalisques o'erflow the moon", a truly original version of Paradise: "Hissarlik, the love pursued / Like a vilayet's white hues / Once by lime and plague o'ergrown, / Nest of veg'table and stone, / Stay the Eden I have known!" The only "philosophy" allowed here is the faultless wisdom of Khodja Nasr-ed-Din, which can fuddle you like a good, old wine: "One wine makes you drink a bit: / Khodja Nasr-ed-Din's own wit". The critic Marin Mincu noticed the monadic self-sufficiency of Khodja Nasr-ed-Din, who refuses the honors offered by the exterior world, and finally consumes himself in autophagy (a radical form of anthropophagy). (Mincu, 131-32) So perfection is perilous and self-destructive, and only poetry can save it from becoming extinct.

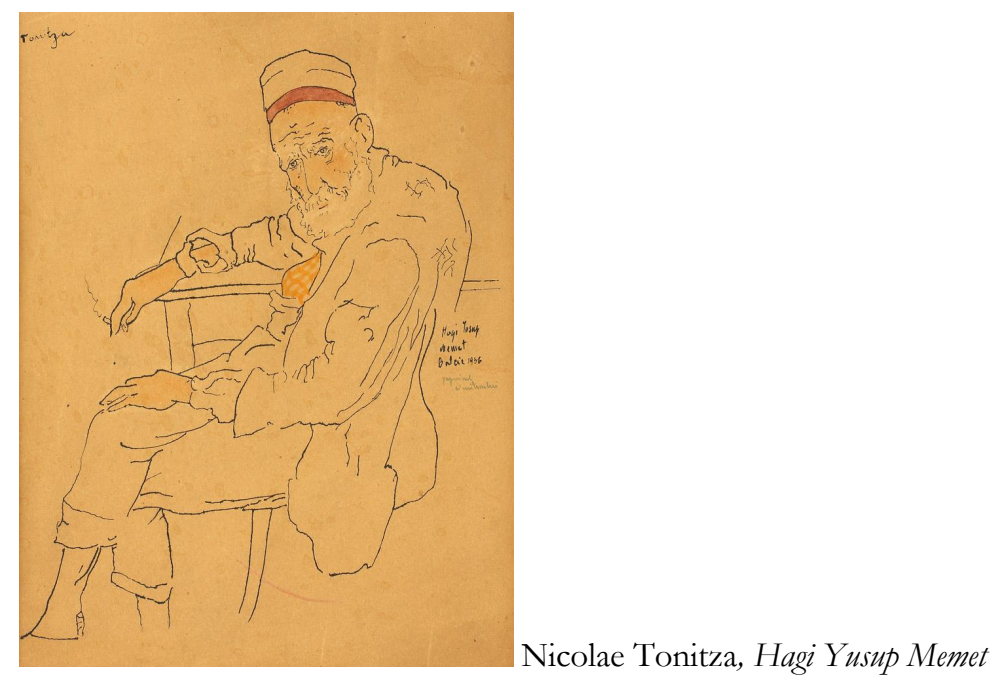

A very interesting approach is to be found in Victor Ion Popa's play Take, Ianke and Cadir (1933), which tells the story of the intercultural brotherhood between three merchants from a small town: the 
Romanian Take, the Jew Ianke and the Turk Cadîr. The play discusses the des/advantages of multicultural communities, the universal values of tolerance, and the necessity for intercultural sensitivity. All of them have lived their entire lives together and helped each other like genuine brothers. After Ianke's spouse has died while taking care of Take's wife, they were widowed and raised their children together, also helped by Cadîr. Now, Take's son and Ianke's daughter are about to graduate from the Academy of Economics, and they plan to get married. The news produces a shock, but their parents do not clearly realize what exactly has triggered this shock. The ethnic and religious otherness is brought to discussion only with the arrival of Elijah, who speaks the great truth that the girl is Jewish and the boy is a Christian. Until now, the fathers' opposition was an abstract one, caused by a vague and irrational fear. Too familiar with the similarities, Take and Ianke did not see the differences clearly. Only at this point they realize that such an intercultural marriage might bring about their bankruptcy, as the local communities would not tolerate it. They do want their children to be happy, but they have to consider all the aspects of this situation.

Their friend and brother Cadîr is also a metaphor of the Oriental wisdom, and an icon of the multicultural Ottoman Empire. He was deeply in love with a Christian woman, however he has sacrificed his true affection to the prejudices, and remained alone and grieving all his life. But beyond the tragic summary of his life, he also illustrates the story of a failed initiation, of the failure to decode the message of destiny. Now he knows that love transcends religions, for all known doctrines place love at the center of their ideology. The genuine love of divinity can only be understood metonymically, through the love of one's neighbor. Love is transcultural, being the bond of all religions. So now, he is trying hard to avoid the reduplication of his tragic destiny. After deep thinking and intense praying to Allah, he becomes a vehicle through which the divine wisdom, which has its own ways to give meaning to human existence, is manifested. The wise Cadîr became worthy to convey to the world this wisdom, being purified by sacrifice and suffering. While the real fathers are thinking about allowing their children to run away from home, pretending to be against their marriage, to prevent bankruptcy, Cadîr does much more - he finds a solution to help them effectively. He invents an ingenious stratagem to raise capital and help the children to start a business. He tells Take that Ana is actually his natural daughter and asks for money to help her. He also tells Ianke that Ionel is his boy and demands a similar loan.

Though Take and Ianke are on the verge of bankruptcy, and quite upset with Cadîr, for stilling their wives, children and businesses, the young couple, hidden in Cadîr's house, invest their money in a prosperous business. After a while, they decide to reveal the whole plan to their fathers. They wedded and they are expecting a child, and they have also invested well (as they have learned at the Academy), the loans indirectly received from their fathers, through Cadîr. After eliminating the local competition, they established a solid and unified company called "Tache, Ianke and Cadîr". The three old friends will now be "technical advisors" of this business, a sort of supermarket, a mini-multinational of the neighborhood.

Many other case studies could be invoked to exemplify the attractiveness of Turkish cultural themes. As a general remark, it is obvious that after Romania gained its independence, in 1877, the tensed relations become inactive, so writers like Caragiale and Ion Barbu were able to express their fascination with the Turkish world, untroubled by their ethnic sensitivity.

The contemporary novel of Silviu Angelescu (born in 1945) The Money Counterfeiters (Calpuranii, 1987), present in school textbooks, and praised by the most prominent Romanian literary critics, is the living proof that the fascination of the Turkish world is still active. The action takes place in Walachia, under the early reign of Nicolae Mavrogheni (1786-1790), and the exquisite historic and linguistic reconstruction has an authentic gust of the old Phanariot Age.

All these case studies (and many others) verify the repeated occurrences of leitmotifs like magnificence, wisdom, lust and leisure, which thus qualify as the most frequent insignias of Turkish identity mirrored by Romanian literature and painting. 


\section{Works cited}

Angelescu, Silviu. Calpuzanii. Bucharest: "Cartea românească” Publishing House, 1987

Barbu, Ion. Hissarlik! Translation by Andrei Bantaş, in vol. Like Diamonds in Coal Asleep. Selection from 20th Century Romanian Poetry. Bucharest: Minerva Publishing House, 1985, 120-22

Bolintineanu, Dimitrie. Opere I-XII, ediție îngrijită de T. Vârgolici, București: Minerva Publishing House, 1981-1992

Cantemirii, Demetrii. Incrementorum et decrementorum Aulae Othmannicae libri tres, Bucharest: "Roza vânturilor" Publishing House, 1999

Caragiale, I.L. Fresh Prime Pastrami. in vol. Sketches and Stories, translated by E. D. Tappe, Cluj-Napoca: Dacia Publishing House, 1979

Cândea, Virgil. "The Original Manuscript of the History of the Ottoman Empire by Dimitrie Cantemir", in Demetrii Cantemirii, Incrementorum et decrementorum Aulae Othmannicae libri tres, Bucharest: "Roza vânturilor" Publishing House, 1999, translated in English by Sergiu Celac

Dafinoiu, Cristina Valentina. "Termeni de origine greacă în opera lui I.L. Caragiale. Studiu de caz: Kir Ianulea" in vol. Actualitatea lui Caragiale 1912-2012, Centrul de Cercetare şi Dezvoltare Profesională "Studiile Româneşti în Context Internațional" (STUR), coord. Marina Cap-Bun and Florentina Nicolae, Bucharest: Musical Publishing House, 2012

Eminescu, Mihai. Third Satire (Scrisoarea III). Translation by Petre Brimm, in vol. Treptow, Kurt W. Classics of Romanian Literature. Selected Works of Ion Creangă and Mibai Eminescu. East European Monographs \& Bucharest: Minerva Publishing House, 1991

Mincu, Marin. Ion Barbu - Eseu despre textualizarea poetică. Bucharest: "Cartea românească” Publishing House, 1981

Nicolae, Florentina. "Note privind religia și civilizația islamică în opera lui Dimitrie Cantemir", in vol. Literatura, teatrul şi filmul. In onoarea dramaturgului Matei Vişniec, Centrul de Cercetare şi Dezvoltare Profesională "Studiile Româneşti în Context Internațional” (STUR), Coord. Marina Cap-Bun and Florentina Nicolae, Constanța: Ovidius University Press, 2015

Pop, Emil T. Vita et Elogium Principis Demetrii Cantemyrii, in Dimitrie Cantemir şi Academia din Berlin [Dimitrie Cantemir and the Academy of Berlin], in "Studii", XI, 1959, no.5

Popa, Victor Ion. Take, Ianke și Cadîr, București: Editura Univers și Teatrul Național „I.L. Caragiale”, 1972.

Tappe, Eric. D. Ion Luca Caragiale, New York: Twayne Publishers, Inc., 1974

Todorova, Maria. Imagining the Balkans. New York: Oxford University Press, 1997 